\title{
INFLUENCE OF SALT STRESS ON THE FLG22 INDUCED ROS PRODUCTION IN ARABIDOPSIS THALIANA LEAVES
}

\section{AMRAHOV NURLAN RASHID ${ }^{1}$, MARTIN JANDA ${ }^{2,3}$, MAMMADOV ZIADDIN MAHMUD ${ }^{1}$, OLGA VALENTOVÁ ${ }^{3}$, LENKA BURKETOVÁ ${ }^{2}$, QULIYEV AKIF ALEKBER ${ }^{1}$}

\author{
${ }^{1}$ Department of Biochemistry and Biotechnology, Baku State University, Baku, Azerbaijan \\ ${ }^{2}$ Institute of Experimental Botany of the Czech Academy of Sciences, Czech Republic \\ ${ }^{3}$ Department of Biochemistry and Microbiology, University of Chemistry and Technology, Prague, \\ Czech Republic \\ *Corresponding author's email:nurlan00686@gmail.com
}

\begin{abstract}
In their natural habitats, plants have to cope with multiple stress factors triggering respective response pathways, leading to mutual interference. Our work aimed to study the effect of salt stress in combination with immune response triggered by microbe-associated molecular pattern (MAMP) in Arabidopsis thaliana Col-0 plants. We measured ROS production after treatment with flg22 and the influence of concomitant salt stress $(\mathrm{NaCl}$ and $\mathrm{Na}_{2} \mathrm{CO}_{3}$ ). The maximum combined effect of $\mathrm{NaCl}$ solution and flg22 on ROS production was achieved at $6 \mathrm{mM}$ salt, which was almost 2 times higher than the single effect of MAMP. A similar maximum combined effect with $\mathrm{Na}_{2} \mathrm{CO}_{3}$ was observed at $10 \mathrm{mM}$ concentration. High concentration of $\mathrm{NaCl}$ and $\mathrm{Na}_{2} \mathrm{CO}_{3}$ was accompanied with declining of ROS production, which was completely inhibited at $150 \mathrm{mM}$ of $\mathrm{NaCl}$ and at $50 \mathrm{mM}$ of $\mathrm{Na}_{2} \mathrm{CO}_{3}$. The immediate and long term $(24 \mathrm{~h})$ effect of $\mathrm{NaCl}$ on leaf tissue of Arabidopsis thaliana showed that the impact of salt stress on flg22induced ROS production probably did not affect the genetic aspects of the tissue response, but was associated with ionic and osmotic stresses .Experiments with mannitol, $\mathrm{KCl}$ and $\mathrm{CaCl}_{2}$ allowed to conclude that the observed effect was due to the ionic stress of the salt rather than the osmotic one.

Key words: Arabidopsis thaliana, flg22, salt stress, ROS production

\section{Introduction}

One of the most common and widely distributed factors in the world that negatively impact on the growth and development of plants, including its productivity, is the salinity of the environment $(1,2)$. Since plants have sessile lifestyle, they are not able to escape from the extreme habitat in which they are located, they have to adapt to this environment to survive. Plants have evolved complex protective mechanisms aimed to prevent these combined negative effects and have created opportunities to adapt to these conditions $(3,4)$. Despite the fact that adaptive responses are complex and multi-stage, they have universal nature and begin with the launch of some biochemical processes. One of them is one of the most important reactions in induction of ROS (reactive oxygen species) production (5), closely related to the process of transmission electrons from NADPH to $\mathrm{O}_{2}$ whichis catalyzed by the membrane-associated NADPH-oxidase enzyme $(6,7)$,in plants called respiratory burst oxidase homolog $\mathrm{D}$ (RbohD).In most cases, along with abiotic stress, plants are affected by biotic stress. In Arabidopsis thaliana plant recognition of pathogen could be realized by its flagellin-sensing 2 (FLS2) receptor kinase which recognizes bacterial flagellin,. After recognition FLS2 binds to co-receptor BAK1 and triggers the events leading to transient high ROS production. Our purpose was to investigate the influence of salt stress $\left(\mathrm{NaCl}\right.$ and $\left.\mathrm{Na}_{2} \mathrm{CO}_{3}\right)$ on the ROS production in Arabidopsis thaliana Col-0 leaves in the presence of the elicitor flg22 (conserved $\mathrm{N}$ terminal $22 \mathrm{AA}$ polypeptide of flagellin).
\end{abstract}

\section{Material and methods}

Plant material: Experiments were carried out on the seedlings of Arabidopsis thaliana plants, (ecotype Col-0). Seeds of A.thaliana were sterilized by $30 \%$ bleach (containing $\mathrm{HCl}$ and Tween) and were sown in Jiffy 7 peat pellets. Seedlings were cultivated under a short-day photoperiod (10h/14h light/dark regime)at $100-130 \mu \mathrm{E} \mathrm{m} \mathrm{m}^{-2} \mathrm{~s}^{-1}, 22^{\circ} \mathrm{C}$ and $70 \%$ relative humidity in Snijders plant growth chamber. They were watered with fertilizer-free distilled water as necessary. After 10 days the seedlings were replaced to the new pot with soil and were grown for 4 weeks. For analyses discs $3 \mathrm{~mm}$ in diameter, prepared from the leaves of four week old plants were used. 
bioRxiv preprint doi: https://doi.org/10.1101/727040; this version posted August 7, 2019. The copyright holder for this preprint (which was not certified by peer review) is the author/funder, who has granted bioRxiv a license to display the preprint in perpetuity. It is made available under aCC-BY-NC-ND 4.0 International license.

Chemical treatments. Discs were incubated in 96-well plate in $200 \mu \mathrm{l}$ of distilled water (control), $6 \mathrm{mM}$ and $150 \mathrm{mM}$ $\mathrm{NaCl}$ or $10 \mathrm{mM}$ and $50 \mathrm{mM} \mathrm{Na} \mathrm{CO}_{3}$ solutions. D-mannitol at concentrations $-0,1 \mathrm{mM}, 1 \mathrm{mM}, 5 \mathrm{mM}, 10 \mathrm{mM}, 50 \mathrm{mM}$, $100 \mathrm{mM}, 300 \mathrm{mM}$ were used as osmotic inducers, where discs were incubated for $20 \mathrm{~h} .6 \mathrm{mM}, 30 \mathrm{mM}, 150 \mathrm{mM} \mathrm{of} \mathrm{KCl}$ and $0,1 \mathrm{mM}, 1 \mathrm{mM}, 30 \mathrm{mM}, 150 \mathrm{mM}$ of $\mathrm{CaCl}_{2}$ were applied as comparative ion stressor factor. The measurement of hydrogen peroxide production was performed for a period of 50-60 min immediately after adding $100 \mathrm{nMflg} 22 \mathrm{on}$ the discs in all cases (for immediate or 20 hours analysis), replaced in reaction mixture. In order to understand the influence of salt stress on the production of ROS in the presence of flg22, we used different concentrations of stressors in two modifications:

Hydrogen peroxide determination: $\mathrm{H}_{2} \mathrm{O}_{2}$ production was determined by the luminol-based assay $(11,24)$. This method is based on the detection of the luminescence released by excited luminol molecules generated after the horseradish peroxidase (HRP), which catalyze oxidation of luminol in the presence of $\mathrm{H}_{2} \mathrm{O}_{2}$. Levels as well as duration of the luminescence are proportional to the amount of $\mathrm{H}_{2} \mathrm{O}_{2}$ produced by elicited leaf discs.

For realization the hydrogen peroxide determination discs were replaced in 96-well plate containing $200 \mu 1$ of reaction mixture, consisting of $17 \mu \mathrm{g} / \mathrm{mL}$ of luminol, $10 \mu \mathrm{g} / \mathrm{mL}$ of horseradish peroxidase (Sigma, P-8125) and $100 \mathrm{nM}$ of flg22.The measurement was performed with a luminometer (Tecan Infinite F200).

\section{Results}

The goal of our study was to determine the impact of salt $(\mathrm{NaCl})$ and alkaline stress $\left(\mathrm{Na}_{2} \mathrm{CO}_{3}\right)$ on the production of ROS, which is synthesized with the participation of the biotic stress factor. By this way we tried to find out the cause of the induction or repression of ROS products under the influence of these combined stresses with the immediate and delayed action of the abiotic stress factors + biotic stressor.

1) 20 hours analysis. The leaf discs were placed in microplates with solutions containing $6 \mathrm{mM}$ or $150 \mathrm{mM}$ of $\mathrm{NaCl}$, $10 \mathrm{mM}$ or $50 \mathrm{mM}$ of $\mathrm{Na}_{2} \mathrm{CO}_{3}, 0,1 \mathrm{mM}, 1 \mathrm{mM}, 5 \mathrm{mM}, 10 \mathrm{mM}, 50 \mathrm{mM}, 100 \mathrm{mM}, 300 \mathrm{mMconcentrations} \mathrm{of} \mathrm{mannitol,} 6$ $\mathrm{mM}, 30 \mathrm{mM}, 150 \mathrm{mM}$ of $\mathrm{KCI}$ and $0,1 \mathrm{mM}, 1 \mathrm{mM}, 30 \mathrm{mM}, 150 \mathrm{mM}$ of $\mathrm{CaCl}_{2}$ for 20 hours (distilled water was used as a control). Afterwards, the saline and distilled water from the microplate were replaced by a reaction medium to determine the presence of hydrogen peroxide.

2) Immediate analysis. The leaf discs were placed in distilled water for 20 hours. Immediately before determination of hydrogen peroxide .were placed the distilled water and added the solution of $10 \mathrm{mM}$ and $50 \mathrm{mM}$ of $\mathrm{NaCl}$ to the reaction mixture.

According to the intensity of the relative luminescence, the use of low concentration of $\mathrm{NaCl}(6 \mathrm{mM})$ enhanced the production of ROS compared to controls, both with immediate (fig.1 A) and after 20 hours of $\mathrm{NaCl}$ treatment analysis (fig.1B). The luminescence intensity in both cases was similar. Soit gradually increased, reached its maximumat10-14 min, then gradually decreased and stopped completely after approximately $30 \mathrm{~min}$. At the maximum values of luminescence under $\mathrm{NaCl}$ salt stress, the level of luminescence in immediate experiments increased 2.06 times as compared with the control, but in 20 hours experiments this increase was 1.83 times. Compare with the control (biotic stressor) high concentrations of $\mathrm{NaCl}(150 \mathrm{mM})$ totally blocked the synthesis of ROS both after immediate application of $\mathrm{NaCl}$ or 20 hours of pre-treatment (fig. 1C, 1D respectively), actually the stimulating effect flg22 under biotic stressor on ROS syntheses disappeared too.

A

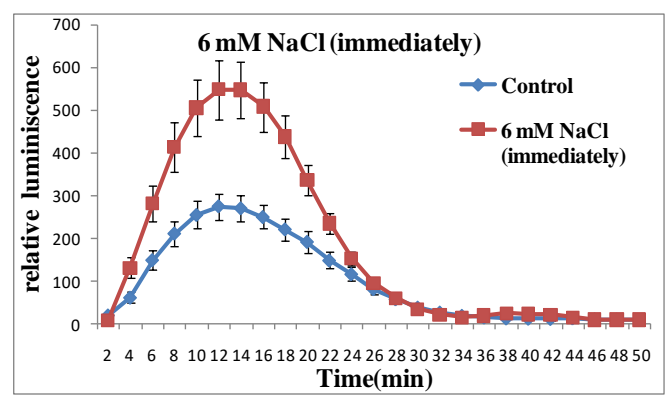

B

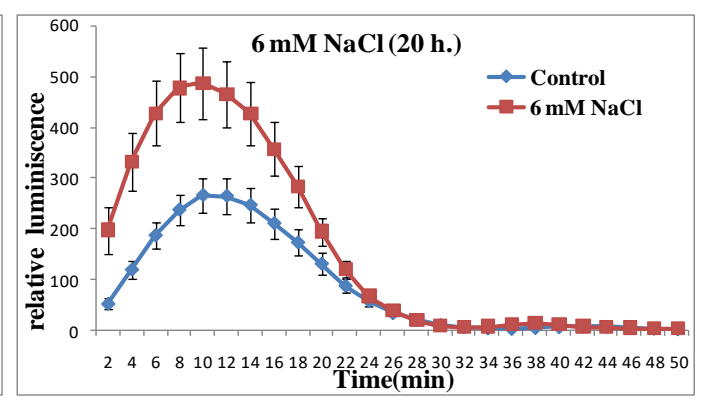


C

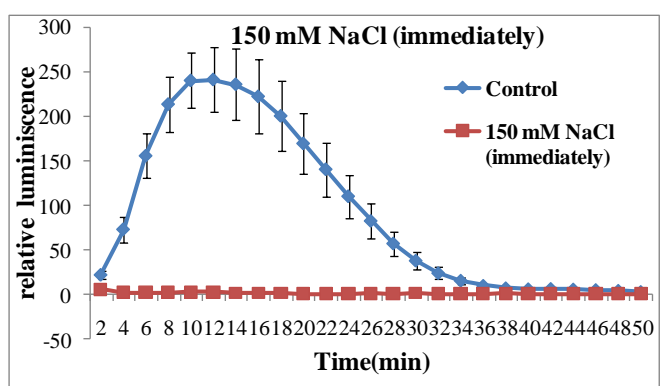

D

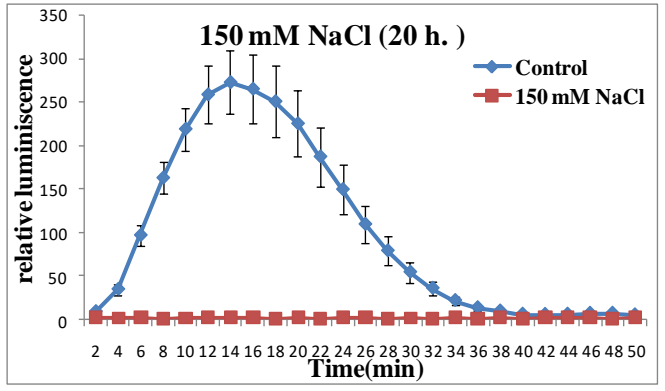

Fig. 1.ROS production of $A$. thaliana leaf discs under NaCI stress in the presence of flg22.

Data represents mean \pm SE (standard error) from 12 independent samples. The experiment was done in two biological replicates with similar results. Both types of samples (control and treated ones) were treated with $100 \mathrm{nM}$ flg22.

Low concentration $(10 \mathrm{mM})$ of $\mathrm{Na}_{2} \mathrm{CO}_{3}$ also enhanced the production of ROS triggered by flg22 (Fig. $2 \mathrm{~A}$ ) substantially, whereas the high concentration of it $(50 \mathrm{mM})$ blocked the synthesis of ROS completely, suppressing in addition to it the effect of flg22 (Fig. 2 B). Checking the $\mathrm{pH}$ of the $\mathrm{Na}_{2} \mathrm{CO}_{3}$ solutions showed that the $\mathrm{pH}$ of both solutions was only slightly different ( $\mathrm{pH}$ of $50 \mathrm{mM} \mathrm{Na} \mathrm{CO}_{3}$ was 11,1 and $\mathrm{pH}$ of $10 \mathrm{mM} \mathrm{Na} \mathrm{CO}_{3}$ was 11,01). According to this fact, we can say that the induction of ROS synthesis was not a consequence of the $\mathrm{pH}$ of the medium.

A

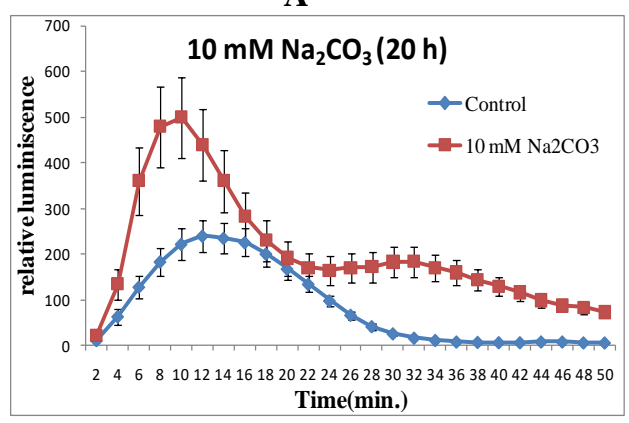

B

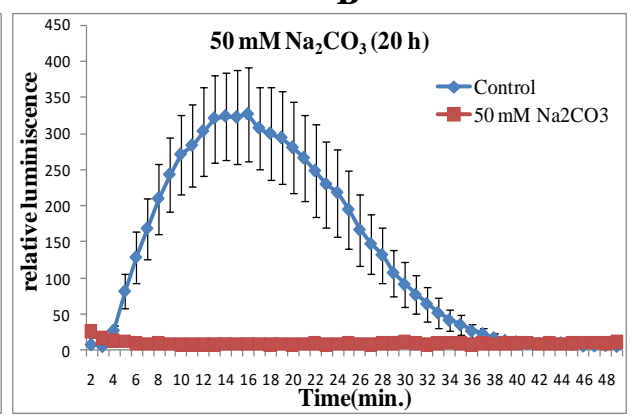

Fig. 2.ROS production of $A$. thaliana leaf discs under $\mathrm{Na}_{2} \mathrm{CO}_{3}$ stress in the presence of flg22.

Data represents mean $\pm \mathrm{SE}$ (standard error) from 12 independent samples. The experiment was done in two biological replicates with similar results. Both types of samples (control and treated ones) were treated with $100 \mathrm{nM}$ flg22.

Salts cause osmotic stress and ion imbalance, which leads to disturbance of membrane ion homeostasis. In order to understand the primary reason of ROS production under the influence of salt stress in the presence of flg22, we tried to investigate this process in more detail. We set a goal to study both of these factors on the ROS production separately. For this purpose, D-mannitol were used as osmotic stress factor, whereas $\mathrm{KCl}$ and $\mathrm{CaCl}_{2}$ as ionic stressors.

The results of the study on the effect of various concentrations of mannitol on the ROS production are presented in Fig. 3. Osmotic stress, caused by mannitol within the concentration $0.1-300 \mathrm{mM}$ did not induce the ROS production, on the contrary, depending on the concentration the synthesis was inhibited directly (Fig.3 A and3B). 
A

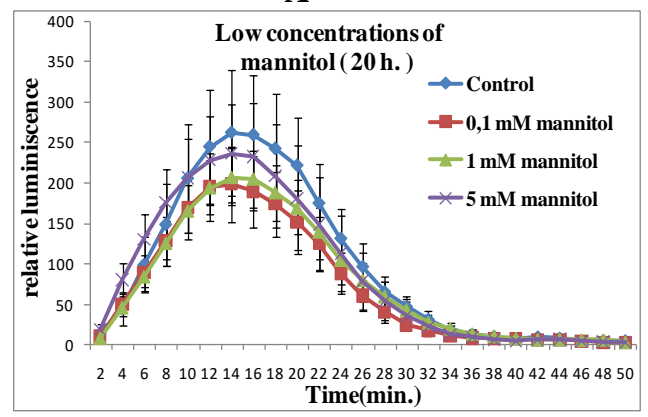

B

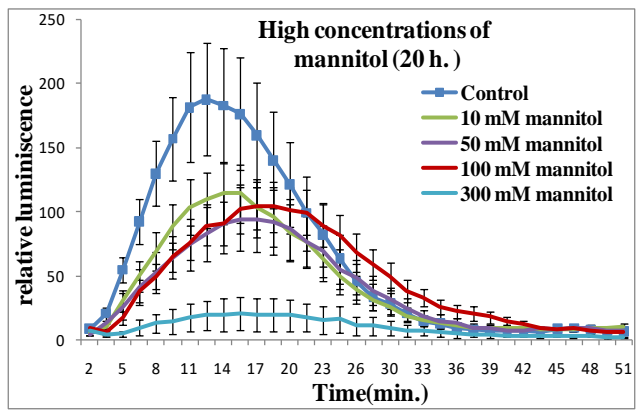

Fig. 3.ROS production of Arabidopsis thaliana leaf discs under osmotic stress in the presence of flg22

Data represents mean $\pm \mathrm{SE}$ (standard error) from 12 independent samples. The experiment was done in two biological replicates with similar results. Both types of samples (control and treated ones) were treated with $100 \mathrm{nM}$ flg22.

Low concentrations of $\mathrm{KCl}$ led to the increase of ROS production, while high concentrations of the salt had an inhibitory effect (Fig. 4 A). This made it clear that with the participation of flg22, Na-K homeostasis was one of the driving forces in the activation and inhibition of ROS synthesis. In comparative experiments with identical concentrations of $\mathrm{NaCl}$ and $\mathrm{KCl}$, it was found that both ions exhibited the same effect, contributing to an increase in the synthesis of ROS (with the participation of flg22), compared to the control (only flg22).This findings again proved our assumption of Na-K homeostasis and its influence on the production of ROS after flg22 treatment (Fig. 4B). It was also demonstrated that $\mathrm{CaCl}_{2}$ had a similar effect as $\mathrm{NaCl}$ and $\mathrm{KCl}$. Low concentration ofCaCI${ }_{2}$ led to the increase, while higher concentrations caused the decrease of ROS production. At $150 \mathrm{mM}$ of $\mathrm{CaCI}_{2} \mathrm{ROS}$ synthesis was blocked totally (Fig. 4 C, 4 D).

A

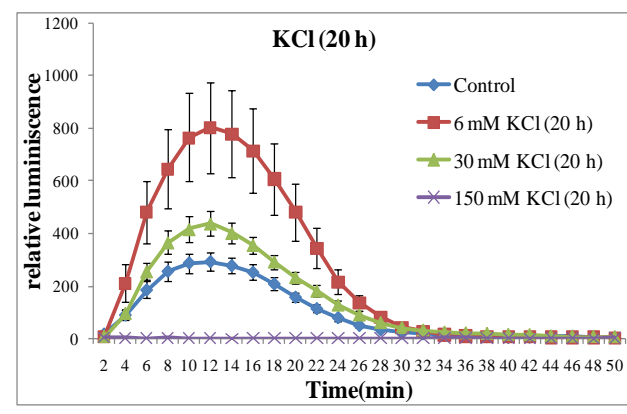

C

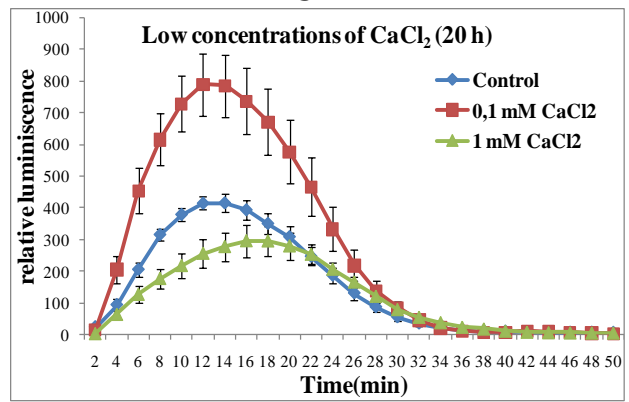

B

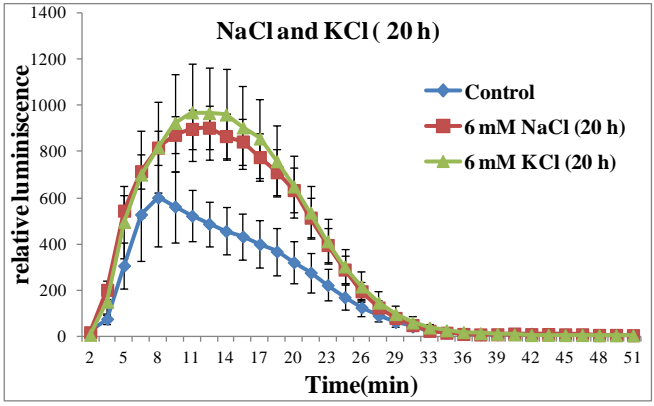

D

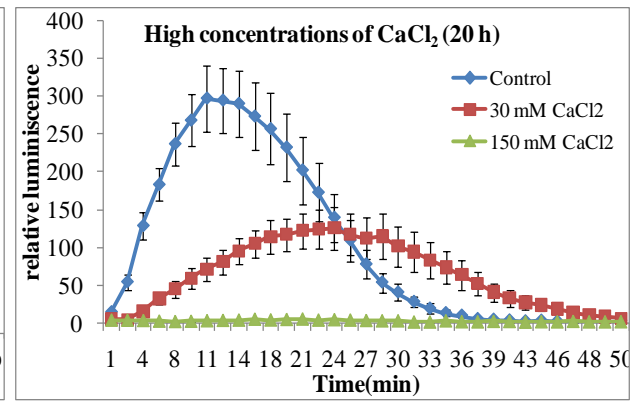

Fig. 4.ROS production of Arabidopsis thaliana leaf discs under ionic stress in the presence of flg22

Data represents mean $\pm \mathrm{SE}$ (standard error) from 12 independent samples. The experiment was done in two biological replicates with similar results. Both types of samples (control and treated ones) were treated with $100 \mathrm{nM}$ flg22. 


\section{Discussion}

In our study, non-genetic mechanisms of activation of ROS were investigated.

We have determined that low concentrations of salt $(6 \mathrm{mM} \mathrm{NaCl})$ and alkaline stress $\left(10 \mathrm{mM} \mathrm{Na}_{2} \mathrm{CO}_{3}\right)$ in the presence of biotic stress (flg22) lead to increased ROS production. At the same time, under similar biotic stress factor, high salinization $(150 \mathrm{mM} \mathrm{NaCl})$ and alkalization $\left(50 \mathrm{mM} \mathrm{Na} \mathrm{NO}_{3}\right)$ were accompanied with a decrease in the production of ROS.

Salt stress, i.e. abiotic stress leads to a disturbance of the Na / K-homeostasis. Ionic stress caused by partial accumulation of $\mathrm{Na}^{+}$in the extracellular space leads to partial inhibition of $\mathrm{Na}^{+} / \mathrm{K}^{+} \mathrm{ATP}-$ ase. As a result, the amount of $\mathrm{Na}^{+}$in the intracellular space increases. And to prevent this phenomenon, in a very short time, the concentration of $\mathrm{Ca}^{2+}$ in the intracellular space increases, which significantly reduces $\mathrm{Na}^{+}$toxicity $(16,17)$.

The effect of biotic stress could be explained as follows.

It is known that the flagellin-sensing2 (FLS2) receptor kinase, which belong to leucine-rich repeat receptor kinases (LRR-RKs), recognizes flg22, that is 22 AAN-terminal peptide of conserved bacterial protein-flagellin. Subsequently, the intracellular domain-BAK1, which is responsible for the transmission of the activation signal to RbohD, was involved in enzyme catalyzing and triggering ROS production(8-10). Activation of BAK1 leads to increased $\mathrm{Ca}^{2+}$ influx by activating GLR3.3. and GLR3.6. channels. An increase in the concentration of intracellular $\mathrm{Ca}^{2}$ ${ }^{+}$affects the TPC1 channel located on the surface of the vacuoles and in turn increases the concentration of $\mathrm{Ca}^{2+}$ which begins to flow additionally from the vacuole into the cytoplasm (18).

The immediate effect of salt stresses + biotic stressor that leading to change of ROS production gives us reason to suppose that the process involves clathrin-mediated endocytosis (CME) (12) and Na-K homeostasis.

As it is already known, salt stress, in particular, sodium-dependent salt stress causes various effects, such as ionic toxicity, oxidative and osmotic stresses (13). The increase in extracellular exogenous sodium ions leads to the disruption of sodium-potassium homeostasis and ROS synthesis occurs. In the moderate stress conditions ROS production and potassium leakage could play an essential role as a 'metabolic switch' in anabolic reactions, stimulating catabolic processes and saving 'metabolic' energy for adaptation and repair needs. But in strong stress conditions these processes could lead to programmed cell death $(14,15)$.

Thus, RbohD under low concentrations of salt, i.e. $6 \mathrm{mM} \mathrm{NaCl}, 6 \mathrm{mM} \mathrm{KCl}, 0,1 \mathrm{mM} \mathrm{CaCl} 2$ and $10 \mathrm{mM}$ $\mathrm{Na}_{2} \mathrm{CO}_{3}$ were subjected to two influences. First one is the effect of the signal that comes from the interaction of flg22FLS2-BAK1-BIK1-RbohD, whereas second one is the involving of additional signal from salt- RbohD interaction. Since, at low concentrations of salt $(6 \mathrm{mM} \mathrm{NaCl})$ and alkaline stress $\left(10 \mathrm{mM} \mathrm{Na}_{2} \mathrm{CO}_{3}\right.$, ) a change in the number of ROS was not observed, and according to literature sources, there was also an increase in the concentration of intracellular $\mathrm{Ca}^{2}$ ${ }^{+}$, we assume that biotic stress plays a key role in starting ROS production. Under the influence of biotic stress, along with an increase in $\mathrm{Ca}^{2+}$ concentration inside the cell, a cascade mechanism is activated to activate the key domains of BAK1, and then BIK1, associated with RbohD. Thus, the activation of the domain BIK1 and launches products ROS. $(19,20)$.

$\mathrm{Ca}^{2+}$, by binding with the EF-hand of NADPH-oxidase, leads to the production of ROS (21- 23).

As already described by Hao $\mathrm{H}$. et al (12), treatment of plants with $100 \mathrm{mM}$ of $\mathrm{NaCl}$ (high concentration) resulted in an increased endocytosis of RbohD and reducing of RbohD on the membrane surface. At the same time a high concentration of salt stress led to degradation of RbohD. In our experiment, high concentrations of salts ( $150 \mathrm{mM}$ $\mathrm{NaCl}, 50 \mathrm{mM} \mathrm{Na} 2 \mathrm{CO}_{3}, 150 \mathrm{mM} \mathrm{KCl}$ and $150 \mathrm{mM} \mathrm{CaCl}_{2}$ ) also led to a decrease in ROS production, which gave us an understanding of the involvement of endocytosis and degradation as negative factors in ROS production.

High salt concentration also led to an osmotic stress. Using D-mannitol as an osmotic stressor, we observed a decrease in ROS production. Consequently, a strong osmotic stress caused by high concentrations of salts or mannitol, combined with biotic stress, leads to a decrease in the production of ROS, and therefore also a weakening of the protective reaction.

\section{Conclusion}

Salt stress, created by low concentrations of $\mathrm{NaCl}$ and $\mathrm{Na}_{2} \mathrm{CO}_{3}$ in the presence of the elicitor flg22 induced the ROS production in Arabidopsis thaliana leaf tissues. Induced ROS production probably affected as the genetic transcriptomic changes aspects of in the tissue response, but also associated with ionic stress. This effect was caused by the changes in ionic strength rather than the osmotic effect.

\section{Acknowledgments}

The work was supported from the International Visegrad Fund, Visegrad Scholarship Program / V4EaP Scholarship Program, under the grant $\mathrm{N}^{\mathrm{o}} 51701351$. 
bioRxiv preprint doi: https://doi.org/10.1101/727040; this version posted August 7, 2019. The copyright holder for this preprint (which was not certified by peer review) is the author/funder, who has granted bioRxiv a license to display the preprint in perpetuity. It is made available under aCC-BY-NC-ND 4.0 International license.

\section{References}

1. Krasensky J., Jonak C. 2012. Drought, salt, and temperature stress-inducedmetabolicrearrangements and regulatorynetworks. Journal of ExperimentalBotany, Vol. 63, No. 4, pp. 1593-1608.

2. Cardia M., Castiglia D., Ferrara M., Guerriero G., Chiurazzib M., Esposito S. 2015. Theeffects of salt stress cause a diversion of basalmetabolisminbarleyroots: Possibledifferentrolesfor glucose-6-phosphate dehydrogenaseisoforms. PlantPhysiology and Biochemistry 86, pp. 44-54.

3. Glazebrook, J. 2005. Contrasting mechanisms of defense against biotrophic and necrotrophic pathogens. Annu. Rev. Phytopathol.43, 205-227

4. Munns R., Tester M. 2008. Mechanisms of salinity tolerance. Annual Review of Plant Biology, v. 59, pp. 651-681

5. Carillo P., Grazia M., Pontecorvo G., Fuggi A., Woodrow P. 2001. Salinity Stress and Salt Tolerance. In book: Abiotic Stress in Plants - Mechanisms and Adaptations, Edition: Book 1, Publisher: INTECH, Editors: ArunShanker, pp. 21-38

6. Panday A., Sahoo M., Osorio D., Batra S. 2015. NADPH oxidases: an overview from structure to innate immunity-associated pathologies. Cellular and Molecular Immunology v.12, pp. 5-23

7. Jeong B. et al. 2018. Oxidative stress caused by activation of NADPH oxidase 4 promotes contrast-induced acute kidney. https://doi.org/10.1371/journal.pone.0191034

8. Kadota, Y., Sklenar, J., Derbyshire, P., Stransfeld, L., Asai, S., Ntoukakis, V., Jones, J.D., Shirasu, K., Menke, F., Jones, A. and Zipfel, C., 2014. Direct regulation of the NADPH oxidase RBOHD by the PRR-associated kinase BIK1 during plant immunity. Molecular cell, 54(1), pp.43-55.

9. Li L, Li M, Yu L, Zhou Z, Liang X, et al. 2014. The FLS2-associated kinase BIK1 directly phosphorylates the NADPH oxidase RbohD to control plant immunity. Cell Host Microbe 15:329-38

10. Pogány M, von Rad U, Grün S, Dongó A, Pintye A, Simoneau P, Bahnweg G, Kiss L, Barna B, Durner J (2009) Dual roles of reactive oxygen species and NADPH oxidase RBOHD in an Arabidopsis-Alternaria pathosystem. Plant Physiol 151: 1459-1475

11. Trujillo, M., 2016. Analysis of the lmmunity-Related Oxidative Bursts by a Luminol-Based Assay. In Environmental Responses in Plants (pp. 323-329). Humana Press, New York, NY.

12. Hao, H., Fan, L., Chen, T., Li, R., Li, X., He, Q., Botella, M.A., Lin, J. (2014). Clathrin and membrane microdomains cooperatively regulate RbohD dynamics and activity in Arabidopsis. Plant Cell 26: 1729-1745.

13. Tuteja, N., 2007. Mechanisms of high salinity tolerance in plants. In Methods in enzymology (Vol. 428, pp. 419-438). AcademicPress.

14. Demidchik V, Cuin TA, Svistunenko D, Smith SJ, Miller AJ, Shabala S, Sokolik A, Yurin V. 2010. Arabidopsis root K+-efflux conductance activated by hydroxyl radicals: single-channel properties, genetic basis and involvement in stress-induced cell death. Journal of Cell Science 123, 1468-1479.

15. Sun J, Li LS, Liu MQ, Wang MJ, Ding MQ, Deng SR, Lu CF, Zhou XY,Shen X, Zheng XJ, Chen SL. 2010. Hydrogen peroxide and nitric oxide mediate $\mathrm{K}^{+} / \mathrm{Na}^{+}$homeostasis and antioxidant defense in $\mathrm{NaCl}$-stressed callus cells of twocontrasting poplars. Plant Cell, Tissue and Organ Culture 103, 205-215.

16. Tian, J. and Xie, Z.J., 2008. The Na-K-ATPase and calcium-signaling microdomains. Physiology, 23(4), pp.205-211.

17. Wu, G.Q. and Wang, S.M., 2012. Calcium regulates $\mathrm{K}^{+} / \mathrm{Na}^{+}$homeostasis in rice (Oryza sativa L.) under saline conditions. Plant, Soil and Environment, 58(3), pp.121-127.

18. Vincent, T.R., Avramova, M., Canham, J., Higgins, P., Bilkey, N., Mugford, S.T., Pitino, M., Toyota, M., Gilroy, S., Miller, A.J. and Hogenhout, S.A., 2017. Interplay of plasma membrane and vacuolar ion channels, together with BAK1, elicits rapid cytosolic calcium elevations in Arabidopsis during aphid feeding. The Plant Cell, 29(6), pp.1460-1479.

19. Suzuki, N., Miller, G., Morales, J., Shulaev, V., Torres, M.A. and Mittler, R. (2011) Respiratory burst oxidases: the engines of ROS signaling. Curr. Opin. Plant Biol. 14, 691-699.

20. Couto, D., Niebergall, R., Liang, X., Bücherl, C.A., Sklenar, J., Macho, A.P., Ntoukakis, V., Derbyshire, P., Altenbach, D., Maclean, D. and Robatzek, S., 2016. The Arabidopsis protein phosphatase PP2C38 negatively regulates the central immune kinase BIK1. PLoS pathogens, 12(8), p.e1005811.

21. Takeda, S., Gapper, C., Kaya, H., Bell, E., Kuchitsu, K. and Dolan, L., 2008. Local positive feedback regulation determines cell shape in root hair cells. Science, 319(5867), pp.1241-1244.

22. Ogasawara, Y., Kaya, H., Hiraoka, G., Yumoto, F., Kimura, S., Kadota, Y., Hishinuma, H., Senzaki, E., Yamagoe, S., Nagata, K. and Nara, M., 2008. Synergistic activation of the Arabidopsis NADPH oxidase AtrbohD by Ca2+ and phosphorylation. Journal of Biological Chemistry, 283(14), pp.8885-8892.

23. Evans, M.J., Choi, W.G., Gilroy, S. and Morris, R.J., 2016. A ROS-assisted calcium wave dependent on the AtRBOHD NADPH oxidase and TPC1 cation channel propagates the systemic response to salt stress. Plant Physiology, 171(3), pp.1771-1784. 

available under aCC-BY-NC-ND 4.0 International license.

24. Janda, M., Lamparová, L., Zubíková, A., Burketová, L., Martinec, J. and Krčková, Z., 2019. Temporary heat stress suppresses PAMP-triggered immunity and resistance to bacteria in Arabidopsis thaliana. Molecular Plant Pathology. 